\title{
Netherworld Messengers: \\ Subversion in the Elizabethan Satiric Pamphlet
}

\author{
ARUL KUMARAN
}

St. Thomas More College

Cet article tente de mieux comprendre la nature du frisson sous-tendant un motif esthétique spécifique et familier du pamphlet satirique élisabéthain: celui du messager infernal. Continuellement transformé par presqu'un siècle de controverses religieuses, et talonnant les pamphlets anticatholiques et antipuritains du milieu du XVI siècle, le pamphlet élisabéthain contenait déjà des traces de sédition et d'hérésie. Ils s'accordaient parfaitement avec la figure du fantôme subversif que l'on trouve dans certains pamphlets de Robert Greene, Thomas Nashe, Henry Chettle et Barnaby Riche. En examinant les pamphlets de Greene, le Pierce Penilesse, his Supplication to the Divell de Nashe et le Kind Hartes Dreame de Chettle, et en examinant en détail le Greenes Newes both from Heaven and Hell, de Riche, qui réutilise le motif du fantôme dans ses pamphlets précédents, cet article montre que ces écrivains élisabéthains étaient conscients du rôle qu'avait le pamphlet satirique en tant que représentation et manifestation d'une énergie sociale subversive, et que la présence fantomatique dans le pamphlet infernal était une forme unique de concrétisation de cette subversion.

$\mathrm{W}$

riting and publishing unauthorized pamphlets in Elizabethan England had an air of rebellion and sedition. This came out of a long tradition of official censorship of print (or at least the perceived threat of censorship and punishment $)^{1}$ and its capacity for free and wide dissemination of information and opinion, especially after the chartering of the Stationers' Company in 1557. Popular and satiric pamphlets, particularly, were targets of an official suspicion that persisted, even deepened, during Elizabeth's reign. The distrust, in turn, spawned a print subculture that was anti-establishment and subversive, ${ }^{2}$ one that articulated society's hidden anarchic energies and its oppositional and dissident views, ${ }^{3}$ while casting doubts on such institutions as monarchy, aristocracy, church, and patronage. Because this print subculture operated under threat 
of persecution and censorship, its subversion was necessarily expressed, often covertly, in codes and allegorical figurations. ${ }^{4}$ This study seeks to understand the social frisson (rage even) behind one particular and familiar aesthetic motif in Elizabethan satiric pamphlets: the "netherworld messenger" was a subversion, a kind of negative social energy, encoded in the arresting figure of the ghost - with the capacity to arouse anxiety not just in a single reader but in a community, especially in those who were culturally dominant and politically powerful. $^{5}$

Pamphleteers such as Robert Greene and Thomas Nashe exhilarated in the subversive potential of their chosen genre. They belonged to a generation of young, educated, ambitious, but ultimately failed writers who did not find proper patronage or profitable employment; they were frustrated and angry, and they found the pamphlet form a perfect medium for expressing their displeasure at the patrons they never had, the authorities who were suspicious of their intentions, and the whole uncaring world in general. Shaped and reshaped by almost a century of religious controversies, and coming on the heels of antiCatholic and anti-Puritan pamphlets in the middle decades of the sixteenth century, the Elizabethan satiric pamphlet already contained traces of sedition and heresy; these dovetailed perfectly with the figure of the subversive ghost found in some of the pamphlets written not only by Greene and Nashe, but also by Henry Chettle and Barnaby Riche. By looking at Greene's cony-catching pamphlets, Nashe's Pierce Penilesse, his Supplication to the Divell, and Chettle's Kind Hartes Dreame, and by closely reading Riche's Greenes Newes both from Heaven and Hell, which self-consciously and brilliantly reuses the ghost motif from these earlier pamphlets, this essay argues that these Elizabethan writers were aware of the satiric pamphlet's role as a representation and manifestation of subversive social energy. Furthermore, the ghostly or demonic presence in the netherworldly pamphlets, written in the last decade of the sixteenth century, is a uniquely realized figuration of this subversion. ${ }^{6}$

The circumstances of John Stubbs's case, an especially interesting example of the pamphlet's subversive potential, reveal the subversive force of the pamphlet during Elizabeth's time. The intensity of the Queen's response to his The Discoverie of a Gaping Gulf (1579), criticizing her determination to marry the Duke 
of Alençon, goes beyond a wounded ego: the pamphlet made her acutely aware of the power of print. ${ }^{7}$ It is not just Stubbs's insults of Alençon, Elizabeth's admirer at that time, but also the dissemination of those insults, the unleashing of them in the public sphere through the agency of print, that seems to have been the reason for Queen's rage. Stubbs's tract made her private affair public and, therefore, somehow seditious. The Queen saw Stubbs's tract as "a lewd and seditious book [...], compiled and secretly printed and afterwards seditiously dispersed into sundry corners of the realm," containing "a heap of slanders and reproaches [...] lies and deceitful speeches"(II: 446). ${ }^{8}$ By these disreputable means, claims her proclamation, the tract "seditiously and rebelliously" stirs up "all estates of Her Majesties' subjects to fear their own utter ruin and charge of Government," and also instills in the people's hearts a "present fear" and "misliking" concerning her marriage. The proclamation's charge of "secret printing and seditious dispersing" is especially noteworthy in light of its anxiety about the effects Stubbs's book would have on the ordinary citizen, who, the proclamation claims, does not have the intellectual ability to discriminate between truth and untruth. The "wiser sorts," according to the writers of the proclamation, are well acquainted "with Her Majesty's honorable and direct proceedings, both in government politic and in a constant maintenance of Christian true religion," and therefore might prove immune to the gossips of the tract. But it is the "simpler sort" of people, the Queen fears, who are in danger of being seduced by it:

The simpler sort and multitude, being naturally affected towards Her Majesty and her safety, might be abused with the fair title of the book and hypocrisy of the author, as well in abusing many texts and example of the scriptures perverted from their true sense, and in interlacing of flattering glosses towards Her Majesty to cover the rest of the manifest depraving of Her Majesty and her actions to her people. (II: 447)

The appeal of the pamphlet in the hands of the ordinary citizen-with its "fair title" and the hypocritical and dangerous interpretations of Holy Scripture that seem to flatter the Queen while subverting her person and authority-is too dangerous for the authorities. The Queen and her counsellors thus reveal an acute understanding of the dangers of wide dissemination of information among common people. The print medium makes official mediation between 
the text and the readers impossible, and thus poses fundamental problems to a society whose order is predicated on surveillance, detection, control, and punishment. The proclamation admits the uncontrollable potency of the printed text: "Her Majesty hath no small cause to be in this sort grievously offended, with such a lewd denunciation to the people, by so common a false libel, like as by a trump of sedition secretly sounding in every subjects ear"(II: 449; emphasis added). The satanic nature of the libellous pamphlet, indirectly hinted at by the apocalyptic imagery of the "trump [...] secretly sounding in every subject's ear," speaks of the anxiety and frustration of the government over the increasingly difficult task of regulating the presses, despite the Stationers' Company's significant powers and virtual monopoly. ${ }^{9}$ In response, the Queen and her counsellors can only resort to the age-old rhetoric of sedition and to threats of destroying the offending machines and men. The defacement and destruction of erring presses are literally extended to the body and the hand of the writer and the printer: the defacement of types is chillingly similar to the amputation of the hands of Stubbs, which leaves both implements (the writing hand and the letter type) impotent and useless. ${ }^{10}$ Nor is the official opprobrium limited to the printer and the writer. Implicated in this sedition is also the reader, who, through his very act of reading the offending material and internalizing it, is in danger of committing treason. The reader's passivity and blamelessness, previously implied in the metaphor of "the trump sounding in the ear" (after all, the ear cannot shut out what it hears), are soon silently revoked, and his or her participation through reading is seen now as collusion. For the Queen's "pleasure and commandment" are made clear:

[No] person which hath regard to her honor should esteem of such seditious book, or the maintainders and spreaders thereof, otherwise than of a traitorous device to discredit Her Majesty both with other princes and with her good subjects, and to prepare their minds to sedition, offering to every most meanest person of judgment, by those kind of popular libels, authority to argue and determine in every blind corner at their several wills of the affairs of public estate, a thing most pernicious in any estate. (II: 449)

Print enables, the Queen affirms, even the "most meanest person" to acquire "judgment" and the authority to argue and determine "the affairs of public estate." 
In her realm, the Queen implies, any agent that effects such empowerment of people is the "most pernicious thing." By the same logic, then, pamphlets, through their intellectual empowerment of readers, are "the most pernicious things" in England in the final decades of the sixteenth century.

\section{III}

Over and over again in the various reigns of Tudor kings and queens in the sixteenth century, unlicensed books and pamphlets, most of them inevitably touching on religion, were proclaimed to be seditious and a threat to the good governance of the realm. The way the authorities portrayed this subversion is interesting for its language and imagery. Right from Henry VIII, all descriptions of offending books and pamphlets are shot through with hints of alienness, an other- and nether-worldliness. Thus these books are "pestiferous" and "pernicious"-indicating that they are a disease that is venomous, stealthy, and capable of infecting the "clean ears of any good Christian man" (I: 183). More importantly, unlicensed print, repeatedly characterized as "books made in the English tongue and imprinted beyond the sea" (I: 194) and "brought from outward parts" (I: 270), was of especial concern to the authorities. ${ }^{11}$ Henry, for example, ordered his subjects not to "bring any manner of English book concerning any matter of Christian religion printed in the parts beyond the seas, into this realm, or sell, give or distribute any English book, printed in outward part, [...] to any person dwelling within this his grace's realm" (I: 375). Queen Mary also habitually complained about books "brought into this realm out of foreign countries and places beyond the seas" (II: 90). Queen Elizabeth unambiguously locates the threat to her and her reign in "certain obstinate and irrepentant traitors, [who] after their notorious rebellions made against their natural country, have fled out of the same, and have remained in foreign parts with a continual and willful determination, to continue all the mischief that they can imagine" (II: 376). Thus official proclamations and pronouncements consciously identified subversive print as alien and foreign.

What comes from outside is also, as we have seen, pestiferous, pernicious, all-pervasive, difficult to control, and hard to attack. It is lewd (carrying within it connotations of lust and therefore possessing an inherent appeal to all human beings) and "evil-disposed" in its very nature. Official pronouncements claim that such writings have been inspired "partly though the malicious suggestion 
of our ghostly enemy, partly by the evil and perverse inclination of seditious disposition in sundry persons" (I: 193-94; emphasis added); these books and tracts are nothing but the "devil [...] setting abroad of his falsehood, as he may many times annexed truths there unto, whereby to induce and deceive the simple people" (I: 374); and the Crown understood them to be the "work of cankered envy and malice and the accustomed wont of such men as be possessed with these spirits" (II: 378; emphasis added). Unlicensed writings and unauthorized views, therefore, are not Christian but demonic, and they come from "beyond the seas" into "this realm" so as to cause its destruction.

The subversion in the religious pamphlet was thus constituted as alien and netherworldly, and this "ghostly" subversion remained with the pamphlet form even when it turned from religious to personal and moralistic polemic in the last decades of the sixteenth century. Aware not only of the innate subversion of their chosen form, these pamphleteers were also keenly alive to the particular characteristic of that subversion: its alien, ghostly, demonic nature. It is this particular, clearly delineated characteristic that we see in some of the more famous Elizabethan pamphlets-ones that self-consciously exploit this connection between subversion and ghost.

\section{IV}

Robert Greene begins this exploitation sometime in 1590 when he broke away from his romance and repentance narratives and started writing satirical pamphlets. ${ }^{12}$ This move is effected in his cony-catching pamphlets. The compiler of these reports is aware of the wickedness of the cony-catchers and the possibility of being accused of consorting with them. But he justifies his foray into the depths of the criminal underworld of London to bring these tales of deception and trickery out in the open on the grounds that they may be a warning to law-abiding citizens of the dangers that lurk within those parts of the city where the cony-catchers roam. ${ }^{13}$ This justification, besides absolving Greene of any responsibility or culpability, seems to sit uneasily with the oddly titillating, morally ambivalent narrative found in these pamphlets. Where in Notable Discovery he is merely a compiler, in the Third Part of Cony-catching he conspiratorially confides in the reader that his pamphlet is actually a report given to him by somebody who knows the ways of the cony-catchers, a Justice of the Peace in fact, who shall remain anonymous. The hint that the exposé 
is actually from a shadowy but credible messenger from the underworld who well knows the trickeries of its denizens is a hilariously elaborate stratagem that winks at the reader and includes him/her in the deception, a deception that may be a defense against any official sanction against the pamphlet; or perhaps it is present simply for the sheer subversive thrill of it. In the Defense of Cony-catching, however, Greene dispenses with the messenger altogether: it is a message sent directly from the underworld, written by a cony-catcher himself (who calls himself Cuthbert Curryknave), vigorously defending his craft by arguing that what he and his companions do in the underworld is not half as wicked as what happens in the Court, the Exchange, and the Inns. Cuthbert's defense is a stinging satire, not only in its arguments but also in the very style: the sympathetic pamphlet voice. In absenting his own voice from this pamphlet, Greene seems playfully to deflect attention from himself; but he, as almost all of his readers would have known, is merely exploiting the genre's subversive nature. ${ }^{14}$

Greene's contemporary and friend Thomas Nashe was even more zealous. His famous work, Pierce Penilesse A Supplication to the Divell, makes perhaps the most explicit use of the satiric pamphlet's subversive potential that we know. Instead of being sent from the nether regions, the message, a supplication to the devil, is sent to them, but Nashe never for a moment disguises the fact that hell is somewhat similar to Westminster or the Exchange. The devil (whom Nashe's alter ego, Pierce, is seeking) is described almost as if he were an early modern robber-baron: a "blind retailer and lender of money upon pawns [...] and so famous a politician [...] that hell (which at the beginning was but an obscure village) is now become a huge city, whereunto all countries are tributary" (I: 158).$^{15}$ In fact, the Knight of the Post-the messenger for Pierce's supplication to the devil-describes hell as being as close to heaven as Calais is to Dover. In an indirect way, Pierce is invoking the cross-channel exchange of books, pamphlets, and letters, implying that his supplication partakes of the politics and dangers of that exchange. Pierce Penilesse is thus an alien and, insofar as it is steeped in the language and metaphor of hell, a deliberately subversive pamphlet.

Pierce Penilesse is a satire about the contemporary state of patronage and the greediness of the patron class, but its main point is its own subversive nature, as boldly and defiantly advertised by its necromantic and atheistic associations. The very origin of the pamphlet, as mock-mythologized by Nashe, is evidence of his flippant, even reckless attitude toward his own work. Pressed by want, he 
says by way of introduction, he "determined to claw Avarice by the elbow, till his full belly gave me a full hand, and let him blood with my pen (if it might be) in the vein of liberality; and so (in short time) was this paper-monster Pierce Penilesse begotten" (I: 161). The mischievous imagery of homosexual copulation and monstrous begetting, along with the subtle hit at patrons ("in the vein of liberality"), treats a potentially dangerous and seamy subject with a certain verbal aplomb, one that effectively disguises Nashe's obvious anger at patrons. It also shows his awareness of his pamphlet as an unnatural entity, one that is ghostly or demonic, fit enough to be sent down to hell into the hands of the devil. The pamphlet as the unnatural or at least the bastard offspring of an impoverished writer searching for legitimacy from a respectable patron is a wellworn trope in the dedicatory and prefatory matter of Elizabethan pamphlets, ${ }^{16}$ but Nashe's ironic twist on this quest for legitimacy from the devil (after all, the pamphlet is intended for him in expectation of gold) stands the Elizabethan conventions of patronage on their head.

This device was later used by other pamphleteers either to sell their own pamphlets or to partake of this subversion. Henry Chettle, for example, in his Kind Hartes Dreame (1593) makes satirical attacks through irony, by using netherworld messengers who pompously repeat the official propaganda against the printing of cheap ballads and vernacular medical texts, the popularity of commercial plays, and such practices as "juggling," i.e. cony-catching. ${ }^{17}$ The messengers are the ghosts of Anthony Now Now, a balladeer; Doctor Burcot, a physician; Richard Tarlton, the famous player; William Cuckoe, a juggler; and Robert Greene, the pamphleteer. Like Pierce Penilesse and Tarltons Newes out of Purgatorie (1590), Kind-Hartes Dreame also cleverly employs messengers from the dead to be satirical without ever being openly critical of authorities. Nashe's Pierce Penilesse had effortlessly ridiculed the widely practised conventions of repentance, patronage-seeking, and estate complaint. Chettle invokes this methodology right in the title page: "Kind-Hartes Dream, containing five Apparitions, with their invectives against abuses reigning. Delivered by several Ghosts unto him to be published, after Piers Penilesse Post had refused the carriage." ${ }^{18}$ The thematic kinship with Pierce Penilesse is pushed further:

When all the five before named had made proffer of several bills invectives against abuses reigning, this devilish messenger repulsed them wrathfully, and bad them get some other to be their packet bearer if they list, for he 
had almost hazarded his credit in hell, by being a broker between Pierce Penilesse and his Lord. (14)

That Kind Harte is the replacement Knight of the Post for these ghosts makes their invectives as much a mad, mock-serious supplication as Pierce's, with one difference: where Pierce's supplication was sent from the real world to the devil, these five are delivered from the netherworld to the real world. As well, the very fact that the pious protestations against "abuses reigning" issue from ghosts to a Kind Harte lying in a drunken haze at a "tap house of Antiquity" alerts us to the carnivalesque nature of the pamphlet. By mock-mythologizing the origin of the pamphlet and by making it a product of the writer's own dream amid "harsh and confused sound," Kind Hartes Dreame renders these invectives ironic and satirical.

However, Kind Hartes Dreame's satire is obscure and, because of its fragmentary nature, its focus refracted. Nor is its force sustained sufficiently through the length of the pamphlet for it to build into a coherent criticism of anything. For that reason, its subversion is a bit lost. But Greenes Newes both from Heaven and Hell, a 1593 pamphlet apparently written by Barnabe Riche, ${ }^{19}$ employs the netherworld motif in unexpectedly effective ways to score some satiric points against Riche's enemies; more significantly, it also effectively exploits the subversion that is implied by and invested in the name and personality of Robert Greene.

Greenes Newes both from Heaven and Hell, an uncharacteristic work by Barnabe Riche, raises the question of why such an established writer-as Riche certainly was in 1593-would write an anonymous pamphlet, evoking the recently dead Greene in satirizing some of his enemies far away from London, in Ireland. Given Riche's circumstances in 1592 and early 1593, his writing of a popular pamphlet, in which a notorious but successful writer who had personified the very popularity and subversion of the pamphlet form figures prominently, indicates not only Riche's understanding of Greene and his death but also the fundamental nature of the pamphlet form..$^{20}$ More importantly, it also points to Riche's view of Greene as a vehicle for satire and subversion, through whom he could vent his own frustrations and anger at his patrons and enemies alike. 
Riche's enemy was Archbishop Loftus of Dublin, against whose "corruption" the writer seems to have carried on a relentless letter campaign with authorities in London. But because of his position, Loftus always had an upper hand and could easily contain Riche's attacks. For example, a letter that Loftus wrote to Burghley shows how thoroughly the Church bureaucracy had mastered the art of impugning dissension against it. Adopting a rhetoric and tone uncannily resembling those royal proclamations against sedition and heresy, Loftus penned not just a vigorous rebuttal of Riche's criticism but a deliberate and ruthless character assassination:

Barnabe Riche, a gentleman of her Majesty's pensioners in the kingdom, whom albeit in life I never offended, yet am I advised by some of his own confederacy that for these twelve months past and more, he and some others have been strict observers of all my doings, and have secretly collected and looked some accusations both against myself and some other of my brethren of the clergy here: which, as he himself hath commonly reported, were delivered to her Majesty's hands at his last being in England, the cause of which his dealing and practice against us I cannot ascribe to any other thing but to the malicious disposition of some papists and atheists in this kingdom (with whom for the most part Riche is conversant) who (to disgrace our persons for our profession's sake) have as I conceive raised him as another Martin to sow the seeds of sedition by this godly course, being a man of himself very needy, by nature immodest and subject to many and very gross infirmities. ${ }^{21}$

The equation of pamphleteering with "malicious disposition" and collusion with subversive elements ("papists and atheists") is a familiar one; but its invocation of the name of Martin Marprelate is a brilliant stroke, as it imputes a certain rhetorical virulence and moral disrepute to Riche's campaign and motives. Riche never recovered from this devastating assault.

Thus described as a political subversive, Riche arrived in London in 1592, aged almost 50 and, having served in Ireland for over 20 years, almost without any prospects in London but probably entertaining hopes of some preferment at Court. He could not get an audience with the Queen, however, so he faced utter destitution in London. Like Greene and Nashe, Riche also felt abandoned by those he had served, and, again like them, Riche had nowhere to turn but to 
the marketplace of print, which alone could alleviate his hunger and perhaps provide an outlet for his frustration. Consequently, seeking to exploit the 1580s fad for romances, he wrote one himself, The Adventures of Brusanus, in October 1592. We can conjecture that it was not very popular when published-it did not see a second edition. ${ }^{22}$ It was the familiar cycle all over: writer is neglected by patrons, writes romance, fails, gets frustrated and angry and turns to popular pamphlets, both for revenge and sustenance. Riche's path to Greenes Newes was a well-trodden one. ${ }^{23}$ But what was uniquely his own was the way he made a motif out of Greene and the way he made his pamphlet remain conscious of its own status as a satirical vehicle through the use of Greene's persona.

Much like Kind Hartes Dreame, this pamphlet was also purportedly received by Riche from the ghost of Robert Greene, who requests Riche to perform "the committing of these papers to the press, wherein [...] I have [...] manifested the very drift of mine own devise [...]" (4). ${ }^{24}$ Ostensibly, it speaks of Greene's journey, after "pitiless Death had summoned [his] soul to leave his transitory estate" (8), through the netherworld. In the main pamphlet itself, Greene meets with Cloth Breeches and Velvet Breeches, two characters from his satiric pamphlet A Quip for an Upstart Courtier, one representing English simplicity and the other Continental foppery; then they walk toward heaven, where a huge crowd waits in front of its gates. This is satirically meant to resemble the hordes of suitors outside Elizabeth's court. Nobody knows when the gates will open, but Saint Peter appears presently and the suits begin. Predictably, he admits Cloth Breeches but not Velvet Breeches; as for Greene, Saint Peter accuses him of exposing only the low-level criminals of London in his cony-catching pamphlets and not the crooks in the upper reaches of society, so Greene is barred from heaven. Dejected, Greene and Velvet Breeches proceed to hell, hoping to find a final resting place at least there. Lucifer meets them at the gate and readily grants Velvet Breeches admission, but Greene again runs into difficulties because the cony-catchers in hell have been mightily displeased with his pamphlet exposure of their living brethren on the earth. Using the same arguments that Saint Peter had used (that Greene exposed only the poor cony-catchers, not the rich ones), the cony-catchers chase Greene out of hell, and the pamphlet ends with Greene's bitter vow to inhabit the dark corners of the earth, such as the Court, exposing the corruptions of the world.

The dedicatory letter makes Riche a pamphleteer in the mould of Greene's R.G., the crime reporter in his cony-catching pamphlets, Nashe's 
Pierce Penilesse, and Chettle's Kind Harte. Just as these personae serve as satiric weapons for their creators, Riche also symbolically adopts a persona that is no longer corporeal. Like all the netherworld satirists, Riche makes contact with a figure from the dead only to distance himself from his own satire. The moment of contact between B.R. and Greene's ghost is telling:

[...] there appeared a most grisly ghost wrapped up in a sheet, his face only discovered, with a pen under his ear, and holding a scroll of written paper in his hand [...]. I remembered myself how old fathers were wont to say, that spirits in such cases, had no power to speak to any man, until they were first spoken unto, and therefore taking into me a constrained courage, I asked him what he was and what was his meaning to trouble me in my passing. (3-4)

In this instance of contact with the netherworld, we see Riche consciously adopting the persona of Greene to make his own "scroll of paper," to make, that is, his own attack on the establishment. Riche knows what kind of persona he is adopting and what it means in the marketplace. In this play between B.R. and ghost, the ghost replies: "I am the spirit of Robert Greene, not unknown to thee (I am sure) by my name, when my writings, lately privileged on every post, hath given notice of my name unto infinite number of people that never knew me by the view of my person" (4). By invoking the ghost of Greene, and taking on his persona for his pamphlet, Riche is perhaps aiming to achieve the same popularity and audience that Greene had enjoyed when alive, when everyone knew him and his writings were displayed on every post; but, more importantly, he also wants to find the right satirical voice for the anger and frustration he felt as a spurned servant of queen and country.

Once the adoption is accomplished, Riche, until now a military and romance writer, changes into a satirical pamphleteer of the nineties, following in the footsteps of Greene and Nashe: satirical, tongue-in-cheek, and seemingly amoral, all characterized by Greene's cony-catching persona and Nashe's Pierce. The new voice has enabled the pamphleteer Riche to break free of the artistic and political conventions of creative writing and to articulate his true feelings through satire and verbal playfulness. Riche particularly exploits Greene's cony-catching trope in the main pamphlet. By resurrecting Cloth Breeches and Velvet Breeches, Riche is also acknowledging Greene's genius for satire. Also, 
in facetiously rejecting Greene from both heaven and hell for the same "crime" of misrepresenting cony-catchers, Riche shows an intelligence that indicates that he perfectly understood Greene's uniquely subversive personality, one that belongs firmly on earth.

If Greene, in his pamphlets, had playfully criticized himself for focusing only on the street-level cony-catchers, Riche also plays up this criticism of Greene through Saint Peter and the hell-dwelling cony-catchers. This strategy gives Riche the opportunity to make his own satirical hits at his social superiors. To quote just a few sentences from a long tirade by Saint Peter:

I have heard of you, you have been a busy fellow with your pen, [... who could] find out the base abuses of a company of varlets that lived by pilfering cozenages, and could you not as well have described the subtle and fraudulent practices of great cony-catchers, such as rides upon footcloths, and sometime in coaches, and walks the streets in long gowns and velvet coats: I am sure you have been in Westminster Hall, where you have seen poor clients animated to commence actions, and to prosecute suits till they have brought themselves to beggary \& when all is spent they are turned off like fools, and sent home by weeping-cross. (17-8)

As we can see, Greene's complex and nuanced use of the cony-catching trope helps Riche unleash his own satire. By making use of Greene's mock-ambivalence about his own cony-catching pamphlets, Riche can portray, with irony, the plight of Greene as a writer in trouble for being soft on the rich and powerful rogues. Consequently, like Cuthbert Curryknave in the Defense of Conycatching, Riche provides an apology for cony-catching that is itself a satire. At the same time, by making Greene the target of both Saint Peter and Lucifer, and denying him access to heaven or hell, Riche has essentially validated Greene's satiric message.

Greene's double rejection shows Riche's sophisticated understanding of the ambivalent status that popular pamphleteers occupied in the Elizabethan literary world. Riche shrewdly points out the unclassifiability of writers like Greene and Nashe and the profound misunderstanding of which they, especially Greene, had been victims. Both Saint Peter and the cony-catchers object to Greene on the same grounds (that Greene was partial to the rich), yet the former is moralistic while the latter are furious at their exposure. The result is 
that Greene is not moralistic enough for heaven and too moralistic for hell. The irony of the situation is the ultimate comment on Greene's, indeed the Elizabethan satiric pamphlet's, unique subversive nature.

That Riche pressed all the right buttons as a satirical pamphleteer is evident from the reaction it aroused in official circles. Greenes Newes caused such consternation that within two months of its publication the Privy Council issued a "warrant directed to Robert Browne, a Messenger of the [Star Chamber], for this apprehending of Barnabe Riche, and as occasion served to require the aides and assistances of her Majesty's public officers as well for the apprehension of the said party as for the bringing him before their Lordships in the company of this bearer." ${ }^{25}$ What transpired of this order nobody knows, but this arrest warrant, along with a brutal assault (sometime after the appearance of this pamphlet) on a country road at the hands of a man with Irish connections, made sure that Riche was soon disabused of any pretensions to the role of a popular, satiric pamphleteer. In 1614 he had so far strayed from his 1592-93 flirtation with satire that he recorded in The Honestie of this Age: "for satiric investigating at any man's private person it is far from my thought" (see the epilogue in that pamphlet). But then, in 1614, Riche was a far different man from the one who wrote Greenes Newes in 1592-93. Thus, for a very brief period in his career, Riche, ripe with resentment and anger, succumbed to the netherworld spirit of Robert Greene and wrote an anonymous, subversive, and satirical pamphlet.

The netherworld pamphlets thus signify an important moment in English literary history-achieving self-consciousness as a subversive weapon while yet a commodity in the marketplace. For the creators of these pamphlets and netherworldly figures, writing was a means to stay above poverty, but it was also a strategy to attack those powers and people who could have enriched them. Thus Greene, Nashe, and Riche used their pamphlets as weapons of subversion, exploiting the satiric edge that they themselves had given it. By invoking the netherworld and its denizens, they shrewdly vented their anger even as they invested the satirical pamphlet with a subversive force that is unique to its form. 


\section{Notes}

1. While revisionist historians of early modern censorship such as Cyndia Susan Clegg have convincingly argued that censorship in sixteenth-century England, especially during Elizabeth's reign, was never consistent, wide, or even severe, the perceived threat of censorship, present through various means-establishment of the Ecclesiastical Council and the Stationers' Company, several injunctions and ordinances, and periodic royal proclamations-kept writers in anxiety. This was especially so after the Gaping Gulf affair in 1576, and their fear reached a peak during the Marprelate controversy in 1590. See Cyndia Susan Clegg, Press Censorship in Elizabethan England (Cambridge: Cambridge University Press, 1997), ch. 1-3. Clegg is arguing against a monolithic censorship structure in Elizabethan England proposed by such critics as Frederic Siebert, Freedom of the Press in England, 1476-1776 (Chicago: University of Chicago Press, 1952); Glynn Wickham, Early English Stages 1300-1576 (London: Routledge and Kegan Paul, 1959-81); and Annabel Patterson, Censorship and Interpretation: The Conditions of Writing and Reading in Early Modern England (Madison, WI: University of Wisconsin Press, 1984). For views similar to Clegg's, see Philip Finkelpearl, “The Comedian's Liberty," English Literary Renaissance 16 (1986), pp. 123-38; Richard Dutton, Licensing, Censorship, and Authorship in Early Modern England (Houndmills, Basingstoke: Palgrave, 2000) and Mastering the Revels: The Regulation and Censorship of English Renaissance Drama (Iowa City: University of Iowa Press, 1991). See also Andrew Hadfield, ed., Literature and Censorship in Renaissance England (Houndmills, Basingstoke: Palgrave, 2001).

2. I am, of course, using the concept of "subversion" in the new historicist sense. As Stephen Greenblatt says in his famous essay "Invisible Bullets": "Subversive is, for us, a term used to designate those elements in Renaissance culture that contemporary audiences tried to contain or, when containment seemed impossible, to destroy" (p. 39), in Shakespearean Negotiations: The Circulation of Social Energy in Renaissance England (Berkeley: University of California Press, 1988), pp. 21-65. It would also be useful to quote from a specialist encyclopaedia: "Subversion is best understood over against the concept of ideology, where ideology is defined as the repertoire of images, themes, and ideas disseminated throughout society by and for a dominant culture. In this context subversion would represent the articulation or 'becoming visible' of any repressed forbidden or oppositional interpretations of the social order. In literature, subversive content 
may be openly manifested as the thematic content of entire works. Alternatively, it might be voiced as an active opposition by one or more characters in a fiction to ideological norms inscribed in a text's structure. Under conditions of persecution and censorship, subversion must perforce become covert. Here, the oppositional or dissident message may be encoded in a work of formal organization, often by means of allegorical displacement" (Michael Bristol, "Subversion," in Encyclopedia of Contemporary Theory: Approaches, Scholars, Terms, ed. Irene Rima Makaryk [Toronto: University of Toronto Press, 1993], pp. 636-37).

3. In light of Alan Sinfield's formulation of "dissident reading," Elizabethan satiric pamphleteers may be said to have "blatantly rework[ed]" familiar and authoritative literary figures and conventions so that they are "forced to yield, against the grain, explicitly oppositional kinds of understanding" (Faultlines: Cultural Materialism and the Politics of Dissident Reading [Berkeley: University of California Press, 1992]), p. 22.

4. "Functional ambiguity," as Annabel Patterson called these codes in her Censorship and Interpretation, p. 19.

5. For more on the new historicist usage of the concept of subversion, see, besides the book by Greenblatt (note 3), also Suzanne Gearhart, “The Taming of Michel Foucault: New Historicism, Psychoanalysis, and the Subversion of Power," New Literary History 28 (1997), pp. 457-80; and Greenblatt, "A Response to Gearhart," in the same issue, pp. 481-82; Hugh Grady, "Containment, Subversion and Postmodernism," Textual Practice 7 (1993), pp. 31-49; G. W. Pigman III, "Self, Subversion, and the New Historicism," Huntington Library Quarterly 52 (1989), pp. 501-08; and Jean E. Howard, “The New Historicism in Renaissance Studies," English Literary Renaissance 16 (1986), pp. 13-43. The new historicist interpretation of subversion is inspired by the writings of Michel Foucault, especially such works as Discipline and Punish: The Birth of the Prison, trans. Alan Sheridan (New York: Vintage Books, 1979); and The History of Sexuality (3 vols.), trans. Robert Hurley (New York: Vintage Books, 1980). For a shorter version of Foucault's ideas on power and subversion, see Michel Foucault, “The Subject and Power," Critical Inquiry 8 (1982), pp. 777-95.

6. Benjamin Boycefirst noted this phenomenon of netherworld messengers: see "News from Hell: Satiric Communications with the Nether World in English Writing of the Seventeenth and Eighteenth Centuries," PMLA 58 (1943), pp. 402-37. Little attention has been paid to these characters since. 
7. See Lloyd E. Berry, John Stubbs's The Gaping Gulf with Letters and Other Relevant Documents (Charlottesville: The University Press of Virginia for the Folger Shakespeare Library, 1968), for a good introduction to the controversy. See also Clegg, pp. 123-37, on the Stubbs affair's relation to Elizabethan censorship. For parliamentary discussions of the Alençon affair, see J.E. Neale, Elizabeth I and Her Parliaments (New York: W.W. Norton, 1966), vol. 1, ch. 9 and 15. For a good biographical account of Elizabeth's affair with Alençon, see Anne Somerset, Elizabeth I (London: Phoenix Giant, 1997), ch. 9.

8. All references to royal proclamations are from Paul L. Hughes and James L. Larkin, eds., Tudor Royal Proclamations, 3 vols. (New Haven, Conn.: Yale University Press, 1964). Following their example, I have, in the interest of uniformity and readability, silently modernized the spelling and punctuation of all the early modern texts quoted in this essay, except titles. References to royal proclamations are followed by volume and page numbers.

9. For information on the Stationers' Company and its powers, see the introduction in Edward Arber, A Transcript of the Registers of the Company of Stationers of London, 1554-1640 (London, 1875-1894), and Clegg, ch. 1-3. On topics related to Stationers' Company powers, see Cyprian Bladgen, The Stationers' Company: A History, 1403-1549 (Cambridge: Cambridge University Press, 1960); W.W. Greg, Some Aspects and Problems of London Publishing Between 1550-1650 (Oxford: Oxford University Press, 1956).

10. Stubbs, along with William Page, the publisher of the pamphlet, lost their hands to the chopping block as punishment. Hugh Singleton, the printer, was spared owing to his advanced years. See Berry, p. xxxvi.

11. Religious persecution in England, of course, sent a considerable number of dissidents and refugees-Catholics and reform-minded Protestants-to the Continent right through the sixteenth century. These refugees wrote, printed, and sent a lot of books and pamphlets from the Continent to England.

12. Many critics have noted the transformation. See Arul Kumaran, "Robert Greene's Martinist Transformation in 1590," Studies in Philology 103 (2006), pp. 243-63. See also Charles Crupi, Robert Greene (Boston: Twayne Publishers, 1986); W.W. Barker, "Rhetorical Romance: The 'Frivolous Toyes' of Robert Greene," in Unfolded Tales: Essays on Renaissance Romance, ed. George M. Logan and Gordon Teskey (Ithaca: Cornell University Press, 1989), pp. 74-97; and Carmine di Biase, “The Decline of Euphuism: Robert Greene's Struggle Against Popular Taste," in 
Critical Approaches to English Prose Fiction 1520-1640, ed. Don Beecher (Ottawa: Dovehouse Editions Inc., 1998), pp. 85-108.

13. For general information about cony-catching pamphlets in Elizabethan England, see A.V. Judge, The Elizabethan Underworld (London: George Routledge \& Sons, 1930); and Arthur F. Kinney's introduction to Rogues, Vagabonds, and Sturdy Beggars (Amherst: University of Massachusetts Press, 1990). For social history, see J. Thomas Kelly, Thorns on the Tudor Rose: Monks, Rogues, Vagabonds and Sturdy Beggars (Jackson: University of Mississippi Press, 1977); John L. McMullan. The Canting Crew: London's Criminal Underworld 1550-1700 (New Brunswick, NJ: Rutgers University Press, 1984); and, especially, A.L. Beier, Masterless Men: The Vagrancy Problem I England 1560-1640 (London: Methuen, 1985). For critical work on Greene's pamphlets, see, among others, Constance C. Relihan, “The Narrative Strategies of Robert Greene's Cony-Catching Pamphlets," Cahiers Elisabethains 37 (1990), pp. 9-15; Paula M. Woods, "Greene’s Conny-Catching Courtesans: The Moral Ambiguities of Prostitution," Explorations in Renaissance Culture 18 (1992), pp. 111-24; Craig Dionne, "Playing the Cony: Anonymity in the Underworld," Genre 30 (1997), pp. 29-50; and Arul Kumaran, "Patronage, Print, and an Early Modern 'Pamphlet Moment,'” Explorations in Renaissance Culture 31 (2005), pp. 59-88.

14. Beier, in Masterless Men, offers the important insight that the problem of vagrancy, though urgent in Elizabethan England, was given an alarmist tone in the conycatching pamphlets of that time, perhaps reflecting a perception of imminent danger from vagrants, where danger was perhaps not so imminent. It is interesting to note Shakespeare's treatment of cony-catchers in his Measure for Measure and the state's paranoia against the loose sexual morality of vagabonds: the Duke in the play neatly conflates the loose sexual morality of Mistress Overdone and her customers with the political rebellion he sees in Lucio's lewd slanders against him. See the important and still-interesting cultural materialist reading of Measure for Measure by Jonathan Dollimore, "Transgression and Surveillance in Measure for Measure," in Political Shakespeare: Essays in Cultural Materialism (2 ${ }^{\text {nd }}$ ed.), ed. Jonathan Dollimore and Alan Sinfield (Ithaca, NY: Cornell University Press, 1994), pp. 72-87.

15. All quotations from Nashe are from R.B. McKerrow, ed., The Works of Thomas Nashe (Oxford: Basil Blackwell, 1958). Volume and page numbers have been given in parenthesis for subsequent quotations. 
16. Dekker, writing in the dedicatory letter to Sir John Hamden, Knight of his pamphlet News from hell brought by the Divells Carrier (1606) makes the clearest connection between legitimacy and patrons by making it a question of parental legitimacy: "Sir, the begetting of books is as common as the begetting of children; only herein they differ, that books, so [...] soon as they come into the world, and give the best words, they call to all men, yet are they driven to seek for a father. That hard fortune follows all and falls into, upon this of mine. It gladly comes to you upon that errand and if you vouch safe to receive it lovingly, I shall account myself and it very happy" (STC 6514).

17. See Alexandra Halasz, The Marketplace of Print: Pamphlets and the Public Sphere in Early Modern England (Cambridge: Cambridge University Press, 1997), for an insightful examination of Chettle's Kind Hartes Dreame, in ch. 2. For Chettle's relationship with other pamphleteers such as Greene and Nashe, see John Jowett, "Notes on Henry Chettle," Review of English Studies 45, nos. 179 \& 180 (1994), pp. 385-88 and pp. 516-22; and Harold Jenkins, The Life and Work of Henry Chettle (London: Sidgwick \& Jackson, 1934).

18. Henry Chettle, Kind-Hartes Dreame, ed. G.B. Harrison (London: John Lane, the Bodley Head, Ltd., 1923), pp. 35-37. Subsequent references to this pamphlet have been parenthesized in the text.

19. The title page of the pamphlet has only the initials "B.R." but it has been accepted by scholars that it is most probably Barnabe Riche. See the introduction in B.R. and R.B., Greenes Newes Both from Heaven and Hell, 1593, and Greene's Funeralls, 1594, ed. R.B. McKerrow (London: Sidgwick and Jackson, Ltd., 1911).

20. For biographical account of Riche during this period, especially his quarrel with the Dublin Archbishop and his subsequent struggles in London, see Thomas M. Cranfill and Dorothy Hart Bruce, Barnaby Rich: A Short Biography (Austin: University of Texas Press, 1953); the introduction in Don Beecher, ed., Barnabe Riche His Farewell to Military Profession (Ottawa: Dovehouse Editions, Inc., 1992), pp. 13-105; and Edward Hinton, Ireland Through Tudor Eyes (Philadelphia: University of Pennsylvania Press, 1935).

21. Quoted in Hinton, p. 57.

22. In a first and frail gesture at satire, Riche created the character Martianus in Brusanus after his enemy Bishop Loftus, but this attack seems buried in that rambling romance narrative and probably did not get any traction at all. For dating of this tract, see Helgerson, "Lyly, Greene, Sidney, and Barnaby Rich's Brusanus," Huntington Library Quarterly 36 (1972/73), pp. 105-18. Also see Don Beecher, 
Barnabe Riche His Farewell to Military Profession, for an interesting discussion on Riche as a romance writer, with particular reference to Brusanus. The character of Martianus may be a satirical portrayal of Loftus, but, on the whole, Brusanus is a long and, for our modern sensibilities, boring Alexandrian romance, numbingly imitative of Lyly, Sidney, and Greene. Elizabethan readers apparently agreed: the pamphlet was not reprinted after 1592.

23. Writers like John Lyly, Robert Greene, Thomas Nashe, and Gabriel Harvey had trodden this familiar road that starts from high-minded works all the way to popular pamphlets. Even Spenser resorted to satire, though he did not enter the pamphlet world, unlike his friend Harvey.

24. B.R. and R.B., Greenes Newes Both from Heaven and Hell, 1593, and Greene's Funeralls, 1594, ed. R.B. McKerrow (London: Sidgwick and Jackson, Ltd., 1911), p. 4. Page reference to subsequent quotations has been given in parentheses in the text.

25. Quoted in Cranfill and Bruce, p. 77. 